\title{
Theorizing Frameworks for English Language Teaching: A Brief Non-Chronological Practice Based Narrative
}

\author{
Mohd Asjad Husain \\ Aligarh Muslim University, Aligarh (India). ORCID: oooo-0oo2-1986-6133. Email: \\ hmasjad.rs@amu.ac.in
}

Received May 12, 2017; Revised July o7, 2017; Accepted July 15, 2017; Published August o6, 2017.

\begin{abstract}
The English Language Teaching (ELT) world is abuzz the discussion on how and why the profession of ELT came into existence. However, its developments in the light of pedagogical practices in different times are seldom discussed. Thus, this paper intends to present a non-chronological practice based brief history of ELT which is important to understand how ELT has taken inspirations from different philosophical trends to evolve itself. It traces the effects of theoretical progress of ELT to help professionals formulate informed classroom practices. It talks about the native centered colonial upbringing of ELT, standardization of ELT through Western means and native favoring pedagogical reforms. The paper divides history of ELT into four periods: (i) the period of whims and traditions, (ii) the period of reforms, (iii) the period of pedagogical awareness and (iv) the period of pedagogical awakening. Also, it conceptualizes frameworks of ELT and presents individual accounts on the history of ELT practices in different periods.
\end{abstract}

Key words: ELT, history of ELT, ELT frameworks, theories, approaches, practices.

\section{Introduction}

Lord Macaulay's (1835) views on education in India provides an insight into the imperialistic agendas and ingenuity of the British in the field of education. He opined about the motive of educating Indian masses while sharing his views about education in India, "to form a class who may be interpreters between us and the millions whom we govern... a class of persons, Indian in blood and color, but English in taste, in opinion, in morals and in intellect" (cited in Khan, 2014. p. 5). For uninhibited thinking, such as this, English Language Teaching (ELT) is always seen as the brain child of colonizers (Kachru, 1983; Canagarajah, 2006; Khan, 1999; 2009). This observation is based on historical evidences which are discussed later in this paper. As ELT was started by natives (missionaries) (Khan, 1999), the early history of ELT (up to reform movement) is based on policies and practices dictated by native policy makers, educational bodies, institutional, scholars and research journals. Policies were designed and materials were produced in English speaking countries for ENL (English as a Native Language) learners by ENL based policy makers, material producers and Li English teachers and were transported to all parts of the words without any consideration of cultural realities and local needs (Kumaravadivelu, 2012; $2003 \mathrm{~b}$ ). It created an environment of uneasiness in ELT profession around the globe which, later, resulted in "saner, more rational, and more practical" (Howatt, 1984. p.129) teaching of English in native as well as non-native countries. This paper attempts to understand the non-chronological practice based history of ELT to touch upon major philosophical, theoretical and pedagogical shifts which changed it from a native facing industry to a local-based profession.

(c) AesthetixMS 2016. This Open Access article is published under a Creative Commons Attribution Non-Commercial 4.0 International License (http://creativecommons.org/licenses/by-nc/4.o/), which permits non-commercial re-use, distribution, and reproduction in any medium, provided the original work is properly cited. For citation use the DOI. For commercial re-use, please contact editor@rupkatha.com. 
This paper conceptualizes a comprehensive framework for ELT practices and provides a practice based historical narrative of ELT by dividing it into four different periods:

i. The Period of Whims and Traditions that is, until the appearance of Reform Movement and the emergence of Direct method i.e. until last quarter of $19^{\text {th }}$ century.

ii. The Period of Reforms, that is, from the beginning of method based language teaching or method era to the appearance of communicative language teaching and such other approaches i.e. until the appearance of Chomsky's Aspects of the

Theory of Syntax in 1965.

iii. The Period of Pedagogical Awareness, that is, period of shift from form based language teaching to the function based language teaching. This period brought communicative awareness in the profession of English language teaching. This period also prepared the field of ELT to abandon the faulty concept of method. It started in 1965 with the appearance of Chomsky's Aspects of the Theory of Syntax in 1965 and lasted in 1989 with the appearance of Pennycook's The Concept of Method, Interested Knowledge, and the Politics of Language Teaching.

iv. The Period of Pedagogical Awakening, that is, it refers to the current period where English language teaching is context sensitive, metanarrative based prescriptivism is rejected or at least challenged in principles and practices e.g. methods, syllabi, materials and such others. It started in 1989, with the appearance of Pennycook's The Concept of Method, Interested Knowledge, and the Politics of Language Teaching to present.

These periods are divided on the reflections of similar practices and attitudes of different participants and stakeholders in ELT. These divisions are not based on watertight chronological compartments, rather they follow ELT practices based on theories of language description and theories of language learning. These theories have potential to affect classroom practices as well as attitude of the stakeholders (details will be discussed separately in the periods).

\section{Theorizing a Comprehensive Framework for ELT practices}

Based on researches on the purpose, content and practice of ELT and with an understanding of theoretical swings, philosophical shifts and pedagogical developments in ELT since it has been taken up as a conscious academic activity based on organized practices firstly by the colonial forces during eighteenth and nineteenth centuries (Khan, 1999) and then by non-native professionals from colonies and other countries in twentieth and twenty first century (Crystal, 1997), this section theorizes a comprehensive framework of ELT to understand the nature and approach of teaching exercises in any given ELT situation from a country/state/university to a specific English language classroom. This framework is holistic in nature, it covers all crucial (i) components of ELT classroom practice - needs analysis, course objectives, learning outcomes, syllabus, material, method and assessment - and their (ii) underlying guiding forces: approach, theory of language description and theory of language learning. Elements of this framework follow the sequence of any English language course i.e. starting from needs analysis and completing with assessment. A graphical model of this framework (see figure 1) is designed and proposed in this paper to provide a concise and compact overview of all the elements of the framework. With a clear representation of approach, theories and practices, the graphical model also enhances understanding of the analysis of any given pedagogical situation and helps to keep 
the discussion on track. As the model shows (see Figure 1), (i) approach, (ii) theory of language description and (iii) theory of language learning are three most important elements which guide ELT and works as a thread to connects all classroom practices. Approach focuses on the intentions and outcomes and decides the purpose of language teaching. Theory of language description provides a linguistic base for syllabus designing, material production, selection, sequencing, gradation of content, assessment models and techniques. Theory of language learning is based on research in the field of psychology. It directs the classroom practices such as teaching methods, strategies and assessment techniques.

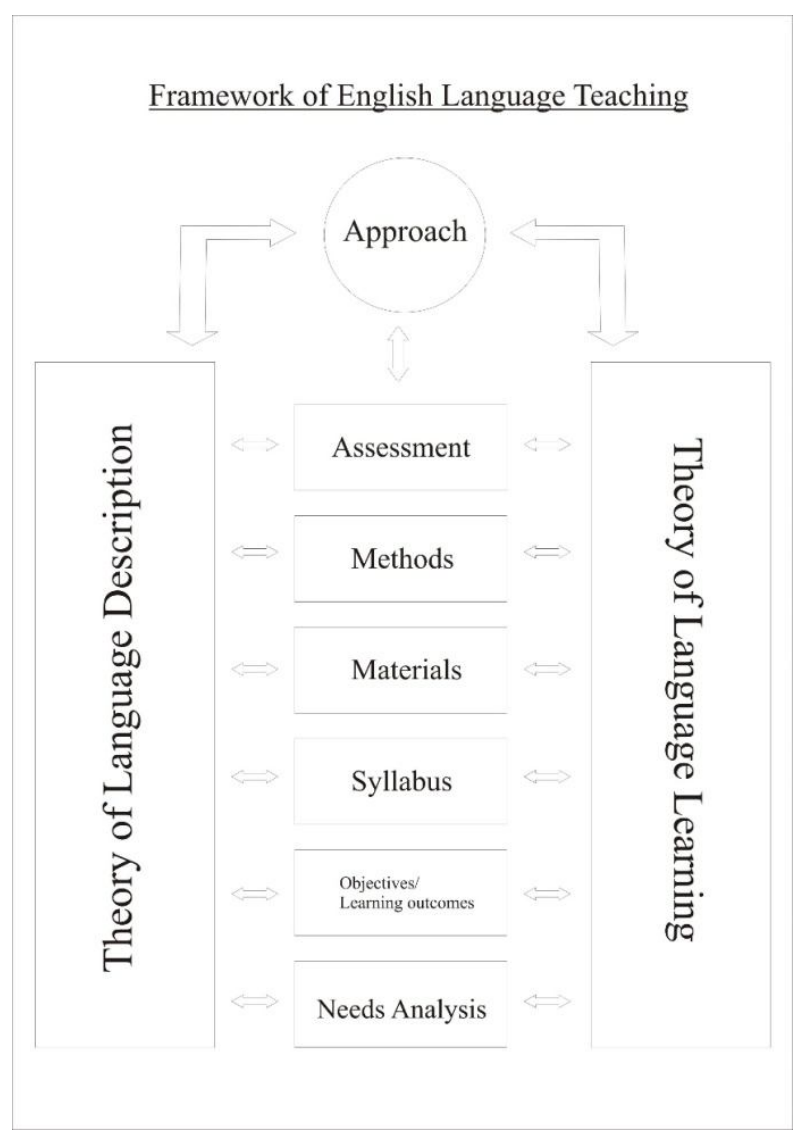

(Figure 1: Framework of English Language Teaching)

To put it in simple words, it can be said that the theory of language description helps in deciding 'what' to teach i.e. content of language courses, theory of language learning guides in deciding 'how' to teach i.e. methodology and classroom procedures and approach provides guidance on 'why' to teach a language i.e. purpose of teaching a particular language course.

These three key elements are the underlying theoretical inspirations and collectively governs all the stages, components and practices of language teaching. They help in deciding how learners' needs will be identified before designing syllabus and producing materials for a language course and how identified needs will modify the course content. The treatment of needs analysis ascertains whether or not course objectives have to be outlined and learning outcomes have to be drafted. Syllabus and materials are guided by the approach of language teaching and the theory of language description and are based on identified needs of the learners and learning outcomes of 
the course. Teaching methods and classroom strategies takes instructions from theory of language learning and tries to achieve the purpose set by the approach.

Assessment is guided by the theory of language description, the theory of language learning and the approach of language teaching alike.

\section{The Period of Whims and Traditions}

This section discusses pre-method and pre-reform periods in English language teaching. Unlike later periods, when ELT became a full-fledged profession and people started calling it an industry, during this period teaching of English was largely based on the individual efforts of language teachers. William Bullokar, William Caxton, Gabriel Meurier, Jacques Ballot, Claudius Holyband, John Florio and William Lily (Howatt, 1984) are some important names of the English language teachers of this period. Although they all taught at different times and places and had their individual styles of teaching of English, but scholars (Kelly, 1969; Howatt, 1984; Richards and Rodgers, 2009) have found one common theme in their teaching i.e. focus on (obsession of) Latin grammar and other syntactical structures. Every aspect of language teaching, from course designing to the final assessment, was based on teaching and testing of grammar. The proposed framework for this period provides a clear account on the practices of ELT.

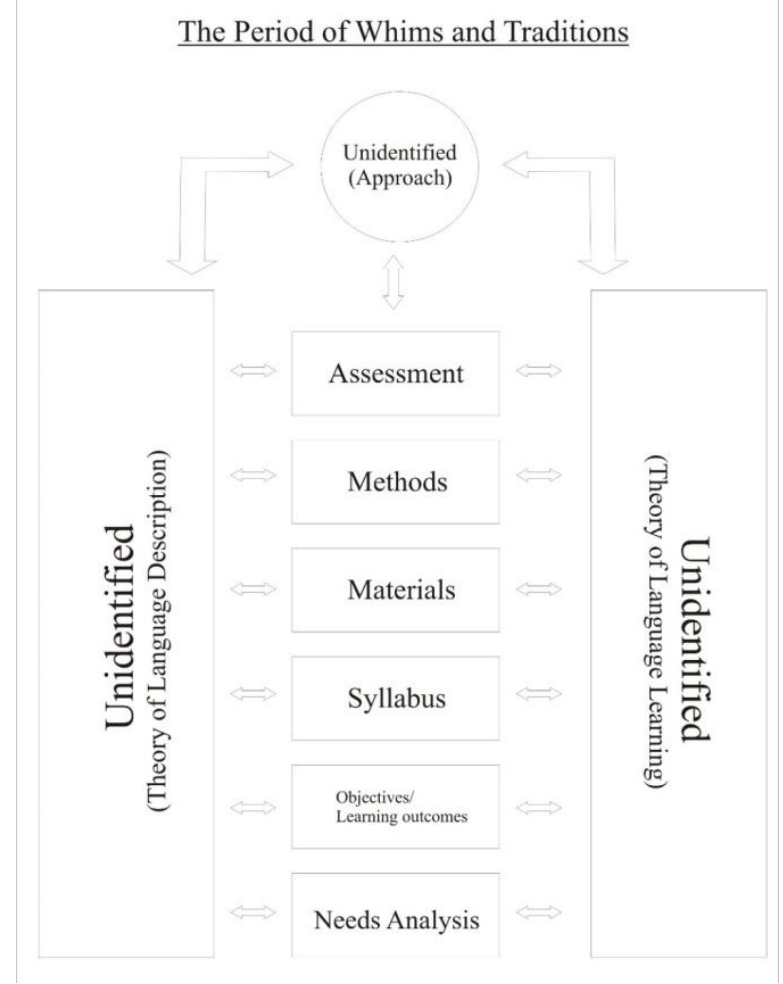

(Figure 2: The Period of Whims and Traditions)

\section{Framework 2}

As the framework shows (see Figure 2), language teachers were completely unaware of theories and different approaches. There can be two reasons for this. (i) the fields of Linguistics and Psychology were not established as separate fields of study or were in an early developmental stage. (ii) Whatever research work was done in these fields could not be spread due to scarcity of 
media resources. Therefore, teaching practices were either based on whimsical ideas or guided by traditions from the teaching of Latin (Howatt, 1984) and other classical languages. Approach to language teaching, theory of language description and theory of language learning was not identified. In fact, these concepts were non-existent or not considered to be relevant for language teaching. There was no consideration of learners' needs. As the outcome of the classroom teaching was not specified, aims, objectives and learning outcomes were also not outlined in advance. Syllabi were based on the random selection of grammatical structures and materials were usually produced by the untrained teachers. William Caxton's Tres bonne doctrine pour aprendre briefment fransoys et engloys or Right good lernyng for to lerne shortly frenssh and englyssh', Gabriel Meurier's double manual, A Lytell treastyse for to lerne Englisshe, Claudius Holyband's Dictionary of French and English and John Florio's The French School Master, The French Littleton, First Fruits and Second Fruits are some examples (Howatt, 1984. pp. 6-41). Traditional classroom strategies and techniques, which were designed to support rote learning and Grammar Translation Method (GTM), were well accepted in each and every classroom. For learners, as Howatt says, "there was no alternative but to rote-learn the text, dimly understood if at all, or risk a beating" (Howatt, 1984. p.32). Punishment was a usual classroom practice in this period. Assessment was purely based on fixed methods such as pen-paper tests. Learners were supposed to reproduce memorized rules. These practices created an environment of dissatisfaction which served as the base of major changes in the field.

\section{The Period of Reforms}

As discussed in the earlier section, faulty language teaching practices created an environment of resentment. Practitioners started opposing Latin based negligent grammar teaching. Joseph Webbe, as Howatt (1984) discusses, proposed an "anti-grammar (no grammar) approach in his book on methodology - An Appeal to Truth, with the view that 'no man can run speedily to the mark of language that is shackled and ingiv'd with grammar precepts"' (Howatt, 1984. p. 34). According to Howatt (1984), Georgius Haloinus Cominius also criticized grammar based teaching, he says, "grammars were long and tedious or short and confusing, and useless either way... languages should never be taught by learning grammar rules but by use and custom" (cited in Howatt, 1984. p. 35). Such emerging thoughts and practices brought a methodological shift and resulted in "Reform Movement" (Richards and Rodgers, 2009) and caused the birth of method era which started with the advent of Direct Method during the last two decades of $19^{\text {th }}$ century. Grammar Teaching was rejected with the criticism that it helps "to know everything about something rather than the thing itself" (cited in Kelly, 1969. p. 53). After this rejection of grammar based teaching, different pedagogical devices emerged "each with a specific method for reforming the teaching" (Richards and Rodgers, 2009. p.7). These devices were based on the principles of Modernism like logic, reason, scientific temperament, observation, rationality, objectivity, globalism, absolutism, universalism and others. These principles gave a solid theoretical as well as methodological base for "a scientific approach to the study of language and of language learning" (Richards and Rodgers, 2009. p. 10) and ultimately resulted in natural methods e.g. Direct Method and such others. The new scientific approach to language learning and teaching "marked the end of prescriptive grammars" (Pennycook, 1994. p.110) and caused the appearance of neoprescriptivism in the form of the concept of method. The proposed framework for this period helps in developing clear idea of how method engulfed 'what' to teach as well as 'how to teach' of ELT from the advent of Direct method to the "spirited 7os" (Akbari, 2008). 


\section{Framework 3}

As the framework shows (see Figure 3), ELT was based on Linguistic approach of language learning and teaching. Structuralism was the theory of language description and behaviorism was the guiding force classroom practices. The situation of the issues of needs analysis, aims, objectives and learning outcomes was similar to the period of whims and traditions. Methods were prescribed as the complete packages of language teaching with the view that they can provide best results in every teaching situation. Syllabi were designed and materials were produced on the lines of structuralism. Teaching forms and structures of English was the primary basis of language teaching. Classroom strategies and techniques were based on behaviorism with the view that language learning is a kind of conditioning and habit formation should be the target of all teaching practices. Therefore, repetition and practice based exercises

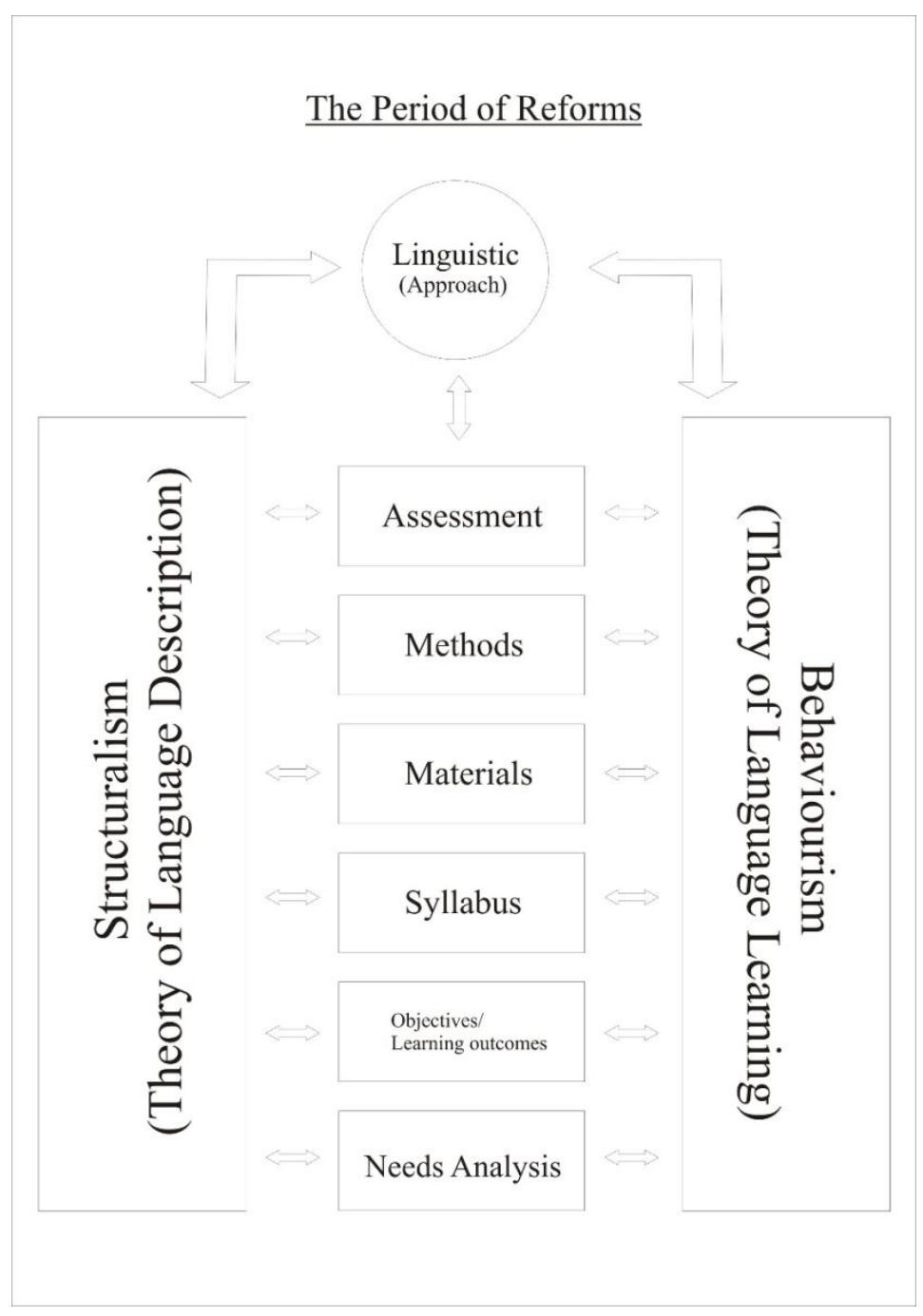

(Figure 3: The Period of Reforms)

were prescribed and practiced. Teacher was the in-charge and the ultimate authority and learners were taken as tabula raza or empty slates to be filled with knowledge entrusted by the teacher. Assessment was also based on inconsiderate product based questions and tedious translation exercises. Despite the fact that the period of reforms was founded on scientific approach towards language learning, it was very similar to the period of whims and tradition because both the 
periods were based on method and were supportive of prescriptivism in language learning and teaching practices (Kumaravadivelu, 2012; 2003b) e.g. the concept of method, standardization of the content of language courses and adherence to native pronunciation models like Received Pronunciation (RP).

\section{The Period of Pedagogical Awareness}

Neo-prescriptivism in the form of method was prevalent throughout the period of Reforms. By the beginning of the second half of $20^{\text {th }}$ century, English language teachers, teacher educators, linguists and other ELT experts started realizing that after

Having witnessed how methods go through endless cycles of life, death, and rebirth, we now seem to have reached a state of heightened awareness- an awareness that as long as we are caught up in the web of method, we will continue to get entangled in an unending search for an unavailable solution, an awareness that such a search drives us to continually recycle and repackage the same old ideas and an awareness that nothing short of breaking the cycle can salvage the situation. (Kumaravadivelu, 1994. p. 28)

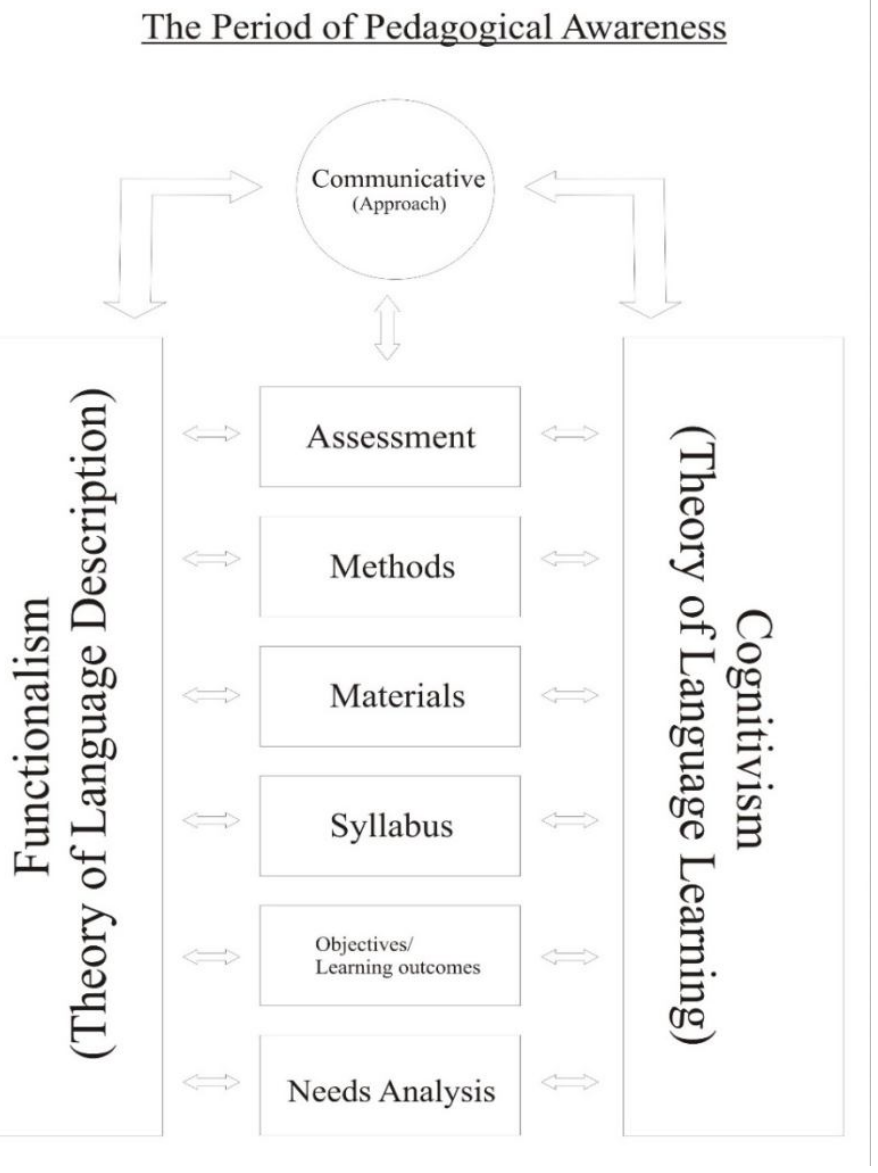

(Figure 4: The Period of Pedagogical Awareness)

This heightened awareness, as Kumaravadivelu calls it, brought enormous changes in the field. This was the period when practitioners started questioning, challenging and even rejecting 
the metanarratives of English Language Teaching: teaching and learning of only native varieties of English, Use of native scholarship based prescribed teaching methods and others. Also, during this period perception towards language changed completely. In earlier periods, language learning was more about the forms and structures of the target language, but in the period of pedagogical awareness, teachers and learners started seeing it as a tool to perform linguistic functions in real life situations. This major shift from formal aspects of English to the functional aspects of English gave birth to the Communicative Language Teaching (CLT). It became the new approach and caused an overhauling of the ELT practices which can be better elaborated with the help of proposed framework for the period of pedagogical awareness.

\section{Framework 4}

The proposed framework for the period of pedagogical awareness shows (see Figure 4) that during this period approach towards English language teaching was changed from linguistic to communicative. But this was not the only big change, rather there was also a shift in the theory of language description and the theory of language learning. With an attention to the functions of the language, Structuralism was replaced by functionalism in English language teaching. Impractical memorization of grammatical structures was left behind and language courses started focusing on functions such as requesting, apologizing, greeting and others. Moreover, behaviorism was also replaced by cognitive psychology and courses started accommodating activities based on the idea of learning by doing and systematic discovery.

As every learner uses language functions differently, analysis of learners' needs gain importance in the eyes of teachers and administrators. Results obtained through needs analysis were thought to be important indicator of learners' success in a particular course. Also, course designers and material producers started setting objectives for language courses and materials. Syllabi were designed and materials were produced keeping in mind needs of the learners and objectives of the course. As syllabi and materials were based on the functions, all language skills i.e. listening, speaking, reading and writing were given their due spaces. This consideration brought academic as well as cultural appropriacy in the field of English language teaching. After the rejection of prescriptive classroom strategies, ELT moved towards the eclectic approach of language teaching. Although eclectic approach was not a method itself, but it was criticized for being dependent on other methods. It allowed teachers to take help from all available models for language teaching without any prescriptive restriction. Classroom practices started becoming more flexible, learners gain importance and teachers started seeking their participation in the learning process. Assessment techniques were also evolved with the change in focus in the teaching process. Oral tests, viva voce and such other techniques were included. Even though these techniques were given negligible weightage, these were considered as a welcomed change. All in all, the period of pedagogical awareness can be seen as a period of transition from traditional approaches to the reformist practices in the field of ELT.

\section{The Period of Pedagogical Awakening}

The period of pedagogical awareness marked a break from conventional practices and provided a base for new ideas and "saner, more rational, and more practical" (Howatt, 1984. p.129) ELT practices. Both experts and professionals in the field acquired pedagogical awareness and fresh attitudes. It made them more flexible, adaptive and welcoming towards further developments in the field. Explorations during the period of pedagogical awareness signaled "a shift away from the 
conventional concept of method toward a postmethod condition" (Kumaravadivelu, 1994. p. 27). Akbari (2008) says that the

profession has gone through a number of dramatic changes during the last two decades. A look at journal articles and topics included in teacher development books shows a broadening of scope in terms of the number and the depth of the topics addressed. Language teaching, one can conclude, has become more inclusive in the sense that more of the reality of the lives of students, and at times those of teachers, are taken on board as significant in affecting the outcomes of teaching and learning (Tudor, 2003). Topics such as World Englishes (Kachru, 1986, 2005), critical applied linguistics (Carlson, 2004; Pennycook 2001; Toolan, 2002), critical discourse analysis (Kumaravadivelu, 1999; Riggins, 1997), ethnography of communication (Harklau, 2005; Hymes, 1996), qualitative research (Davis, 1995; Richards, 2003), and linguistic imperialism (Phillipson, 1992, 2003) have turned into common themes of discussion and research. The social/ political consciousness one observes in the profession was certainly lacking during most of the 1980s. (p. 641)

With this newly acquired socio-political awareness, the field of ELT "parted with its quest for metanarratives and grand theories" (Akbari, 2008. p. 641) and became involved in context sensitive autonomy based teaching practices. Talking about these two consecutive periods Kumaravadivelu (2006) says:

If the first period is called a period of awareness, the second may be called a period of awakening. I focus on the nature and scope of the transition from awareness to awakening, along with the contributions and consequences associated with it. For the sake of synthesis, organization, and presentation, I frame this overarching transition in terms of three principal and perceptible shifts: (a) from communicative language teaching to task-based language teaching, (b) from method-based pedagogy to postmethod pedagogy, and (c) from systemic discovery to critical discourse. (pp. 59-6o)

During this period, learners' status is elevated and teachers are empowered and their roles are changed. Learners are not the passive recipients anymore, rather they are considered partners by teachers and classroom practices are based on their active participation. Kumaravadivelu (1994) seeks to

refigure the relationship between theorizers and teachers by empowering teachers with knowledge, skill, and autonomy. So empowered, teachers could devise for themselves a systematic, coherent, and relevant alternative to method, one informed by principled pragmatism... that will enable teachers to theorize from practice and practice what they theorize. (p. 27)

Prabhu (1990) also talks about a similar "concept (or theory, or, in a more dormant state, pedagogic intuition) of how learning takes place and how teaching causes or supports it is what may be called a teacher's sense of plausibility about teaching" (p. 172). Both Prabhu (1990) and Kumaravadivelu (1994) support teachers' empowerment to put postmethod approach into practice by enabling them to contribute to the teaching and learning practice in a more practical way than only by following experts' instructions in the form of method. These changes can be better described with the help of proposed framework for the period pedagogical awareness. Apart from this, the period of pedagogical awakening has also marked the emergence of Multiple intelligences (MI) (Gardner, 1993; Armstrong, 1994), Autonomy (Chan, 2001; Cotterall, 1995; Dam, 
1995; Holec, 1981; Little, 1991), Critical Thinking (Freire, 1973; Davidson, 1994, 1995, 1998; Brown, 2004), Constructivism (Duffy \& Jonassen 1991; Duffy \& Cunningham, 1996; Fosnot, 1996; Perkins, 1991)

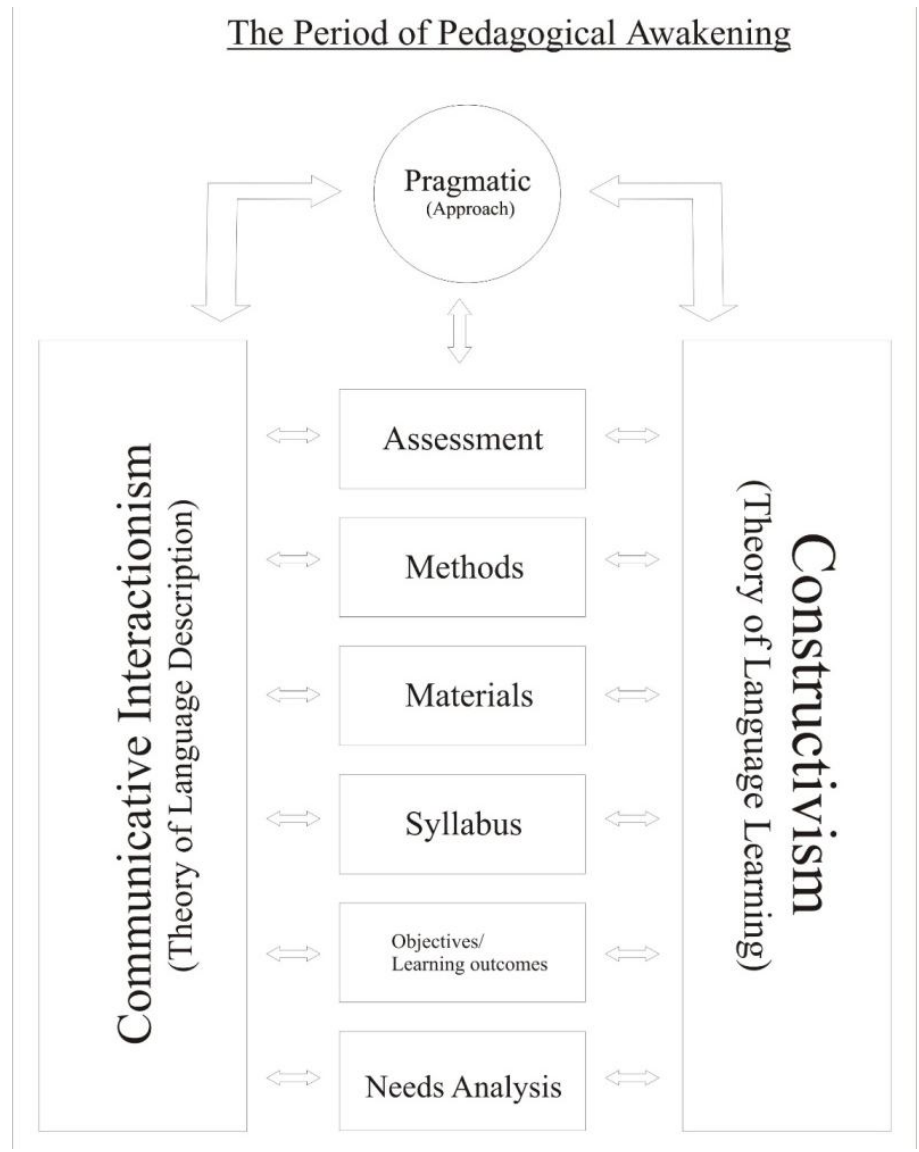

(Figure 5: The Period of Pedagogical Awakening)

\section{Framework 5}

The period of pedagogical awakening (as shown in Figure 5) is an extension of its preceding period both theoretically and practically. The approach towards ELT was improvised from communicative to pragmatic, where learners are expected not only to learn the linguistic aspects of communication but also the social and cultural aspects of it. Likewise, theory of language description, i.e. communicative interactionism, is an extension of previous functionalism with an added focus on multi-channel dynamic processes of human interaction and theory of language learning i.e. constructivism is a successive and advanced stage of cognitivism (Ertmer \& Newby, 1993). In the period of pedagogical awakening mental processing of linguistic input is not sufficient unless learners can understand, construct and create linguistic concepts with practically demonstrating them. The practice of needs analysis, added more dimensions to seek a clearer idea of learners and learning like, focus on learning strategies and learners' autonomy, can also be called preference analysis. Well defined course objectives and thoughtfully outlined leaning outcomes are steering of systematic language learning. Syllabi are negotiable and not fixed as they used to be in the past. Both learners and teachers are allowed and expected to alter syllabus according to a particular classroom and its participants. Materials are based on localism and incorporates local aspects of day to day lives of learners. Classroom practices, unlike earlier 
periods when these were based on methods or eclecticism, are based on principled pragmatism. It is based on or is a result of teachers' empowerment of "sense of plausibility" (Prabhu, 1990. p. 172) where teachers seek to:

(a) maximize learning opportunities, (b) facilitate negotiated interaction, (c) minimize perceptual mismatches, (d) activate intuitive heuristics, (e) foster language awareness, (f) contextualize linguistic input, (g) integrate language skills, (h) promote learner autonomy, (i) raise cultural consciousness, and (j) ensure social relevance. (Kumaravadivelu, 1994. p. 32)

in their practice of English language teaching assessment as more practical and cyclic. It does not focus on language performance at a given point of time as it was a norm in earlier periods, rather it seeks to examine learners' progress and language development in a given period of time.

\section{Conclusion}

This paper began with the premise that a non-chronological practice based historical narrative of ELT is needed to provides in-service English teachers, future English teachers and other ELT professionals a brief and compact overview of how English language has been taught in different times. It traces history of ELT by dividing it into four different periods based on pedagogical exercises and related inspirational theories. Details of each period are discussed with the help of a comprehensive framework conceived in this paper. The divisions are not done on point of time basis rather on period of time basis to accommodate and provide temporal space for pedagogical shifts. It talks about different theories of linguistics, psychology and philosophy, traces their effects on ELT practices and presents an intersectional discussion on theories and practices. This paper provides future researchers and teachers a practice oriented theoretical bridge between philosophies and theories and ELT profession with current theoretical and pedagogical insights to help them navigate their research and design classroom activities with a comprehensive understanding of different aspects of ELT.

\section{References}

Akbari, R. (2008). Postmethod Discourse and Practice. TESOL Quarterly vol. 42, 641-652.

Armstrong, T. (1994). Multiple Intelligences in the Classroom. Alexandria, Va.: Association for Supervision and Curriculum Development.

Brown, H.D. (2004). Some Practical Thoughts about Students- Sensitive Critical Pedagogy. The Language Teacher, 28 (7) (2004), pp. 23-27.

Canagarajah, A. S. (2006). TESOL at forty: What are the issues? TESOL Quarterly, 40, 9-34.

Chan, V. (2001). Readiness for learner autonomy: What do our learners tell us? Teaching in Higher Education, 6(4). 505-519.

Chomsky, N. (1965). Aspects of the Theory of Syntax. Cambridge, Massachusetts: The M.I.T. Press

Cotterall, S. (1995). Readiness for Autonomy: Investigating Learner Beliefs. System, 23(2), 195-206.

Crystal, D. (1997). English as a Global Language. Cambridge University Press, Cambridge. 
Dam, L. (1995). Learner Autonomy: From Theory to Classroom Practice. Dublin: Authentik.

Davidson, B. (1994). Critical thinking: A Perspective and Prescriptions for Language Teachers. The Language Teacher, 18 (4) (1994), pp. 20-26.

Davidson, B. (1995). Critical thinking Education Faces the Challenge of Japan. Inquiry: Critical Thinking Across the Disciplines, 14 (3) (1995), pp. 41-53

Davidson, B. (1998). A Case for Critical Thinking in the English Language Classroom. TESOL Quarterly, 32 (1998), pp. 119-123.

Duffy, T. M. \& Cunningham, D. J. (1996). Constructivism: Implications for the Design and Delivery of Instruction. In D. H. Jonassen (eds.), Handbook of Research for Educational Communications and Technology (pp. 170- 198). New York: Simon \& Shuster Macmillan.

Duffy, T.M. \& Jonassen, D.H. (1991). Constructivism: New Implications for Instructional Technology? Educational Technology, 31(5), 7-11.

Ertmer, P. A. \& Newby, T. J. (1993). Behaviorism, Cognitivism, Constructivism: Comparing Critical Features from an Instructional Design Perspective. Performance Improvement Quarterly, 6(4), pp. 50-72.

Fosnot, C.T. (1996). Constructivism: A Psychological Theory of Learning. In Fosnot, C.T. (ed.), Constructivism: Theory, Perspectives, and Practice. (pp: 8-33). New York and London: Teachers College Press.

Freire, P. (1973). Education for Critical Consciousness. New York: The Seabury Press.

Gardner, H. (1993). Multiple Intelligences: The Theory and Practice. New York: Basic Books.

Holec, H. (1981). Autonomy in Foreign Language Learning. Oxford: Pergamon Press.

Howatt, A.P.R. (1984). A History of English Language Teaching. Oxford: Oxford University Press.

Kachru, B. B. (1983). The Indianization of English-The English Language in India. Delhi: Oxford University Press.

Kelly, L. (1969). 25 Centuries of Language Teaching. Rowley, Mass.: Newbury House.

Khan, J. (2014). Linguistic Imperialism, Politics of Translation and English Studies: Reconnoitering the Impact through Select English Translations in Colonial India. (Unpublished Doctoral thesis). Aligarh Muslim University, Aligarh.

Khan, M.R. (1999). Policy and Provisions for ESL in India's Higher Education. Natraj Publishing House, Delhi.

Khan, M.R. (2009). From 'Twice born' to Global English: The Question of Liberalization and Standardization. English Studies in India. Vol. XVII, January, 2009. pp. 29-54.

Kumaravadivelu, B. (1994). The Postmethod Condition: (E)merging Strategies for Second/Foreign Language Teaching. TESOL Quarterly, Vol. 25, No. 1. (Spring, 1994), pp. 27-48.

Kumaravadivelu, B. (2003b). Critical Language Pedagogy - A Postmethod perspective on English Language Teaching. World Englishes, Vol. 22, No. 4, pp. 539-550.

Kumaravadivelu, B. (2006). TESOL Methods: Changing Tracks, Challenging Trends. TESOL Quarterly, Vol. 40, 59-81.

Kumaravadivelu, B. (2012). Individual identity, cultural globalization and teaching English as an international language: The case for an epistemic break. In Alsagoff, L., Renandya, W., Hu, Guangwei \& McKay, S. (eds.). Teaching English as an International Language: Principles and Practices (pp. 9-27). New York: Routledge

Little, D. (1991). Learner Autonomy: Definitions, Issues and Problems. Dublin: Authentik 
Pennycook, A. (1989). The Concept of Method, Interested Knowledge, and the Politics of Language Teaching. TESOL Quarterly, Vol. 23. No. 4. December 1989. (pp. 589-618).

Pennycook, A. (1994). The Cultural Politics of English as an International Language. Longman, England.

Perkins, D.N. (1991). What Constructivism Demands of the Learner. Educational Technology, 39(9), 9-21.

Prabhu, N.S. (1990). There Is No Best Method-Why? TESOL Quarterly, Vol. 24, No. 2. (Summer, 1990), pp. 161-176.

Richards, J. C. and Rodgers, T.S. (2009). Approaches and Methods in Language Teaching. Cambridge University Press, Cambridge. TESOL Quarterly, 32 (1998), pp. 119-123.

Mohd Asjad Husain is a former Fulbright Foreign Language Teaching Assistant (FLTA) at University of California, Davis and a research scholar in the Department of English, Aligarh Muslim University, India. His areas of interest are decolonization and ELT, second language learning, postmodernism in ELT, autonomy in language teaching and critical pedagogy. 